\title{
Socio-economic impact of biological control of mango mealybug in Benin
}

\author{
Aimé H. Bokonon-Ganta ${ }^{a}$, Hugo de Groote ${ }^{\mathrm{b}, \mathrm{c}, *}$, Peter Neuenschwander $^{\mathrm{c}}$ \\ ${ }^{a}$ Service Protection des Végétaux, Direction de l'Agriculture, B.P. 58, Porto-Novo, Benin \\ ${ }^{\text {b } C I M M Y T, ~ P . O . ~ B o x ~} 25171$ Nairobi, Kenya \\ ${ }^{\mathrm{c}}$ Plant Health Management Division, International Institute of Tropical Agriculture, B.P. 08 0932, Cotonou, Benin
}

Received 15 January 2001; received in revised form 11 October 2001; accepted 20 October 2001

\begin{abstract}
Mango mealybug, an exotic pest of mango, was first observed in Benin in 1986. In a biological control programme, natural enemies were successfully released in the following years. The present study is the first attempt to measure the impact of the biological control of mango mealybug over a large area, through a survey of mango producers. Most producers attributed the observed improvement of mango production to the success of biological control. Based on production estimates by producers, the negative impact of the pest on plant production and the positive impact of the introduced natural enemy were demonstrated. Interviewed mango producers gained on average US\$ 328 per year by the biological control programme. Extrapolated to all producers of Benin, a yearly gain of US\$ 50 million in mango production can be estimated. The present value of accrued benefits is estimated at US\$ 531 million over a period of 20 years. The total cost of the biological control of mango mealybug is estimated at US\$ 3.66 million, which includes initial costs in other African countries and the introduction of the natural enemy from India, resulting in a benefit-cost ratio of 145:1 for benefits in Benin alone.
\end{abstract}

(C) 2002 Elsevier Science B.V. All rights reserved.

Keywords: Economics of biological control; Mango; Rastrococcus invadens; Gyranusoidea tebygi

\section{Introduction}

Mango (Mangifera indica L., Anacardiaceae), an ancient fruit of Indian origin, is of great importance to millions throughout the tropics (Singh, 1968; de Laroussilhe, 1980; Litz, 1997). It is sold on local markets in Africa and constitutes an important source of energy and nutrients (Vitamins A, C, and D, amino acids, carbohydrates, fatty acids, minerals, organic acids, proteins). Mango is also a valuable ornamental and shade tree and contributes to the protection of

\footnotetext{
* Corresponding author. Tel.: +254-2-524600; fax: $+254-2-524601$.

E-mail address: h.degroote@cgiar.org (H. de Groote).
}

soil against erosion. Different medicinal virtues are known (D'Almeida, 1995).

Until recently, damage by insect pests and diseases on mango in Africa was insignificant. In 1986, however, a mealybug, later described as Rastrococcus invadens Williams (Homoptera: Pseudococcidae) of South East Asian origin (Williams, 1986), was reported to cause serious damage to various fruit trees, especially mango, in Benin, Ghana and Togo (Agounkè et al., 1988).

In 1987/1988, a biological control project involving the Gesellschaft für technische Zusammenarbeit (GTZ), CAB International (CABI), the Food and Agriculture Organization (FAO) of the United Nations, and the International Institute of Tropical Agricul- 
ture (IITA), under the auspices of the Inter-African Phytosanitary Council, together with the national programmes of Togo and Benin (Service Protection des Végétaux, SPV), was started. Later many more West African countries joined. The parasitic wasp, Gyranusoidea tebygi Noyes (Hymenoptera: Encyrtidae) was imported from India (Narasimham and Chacko, 1988) and studied in quarantine (Willink and Moore, 1988). The wasp was reared, released and established in different places in Africa (Agricola et al., 1989; Neuenschwander et al., 1994).

In Benin, 10 batches of the first parasitoid G. tebygi were released at different sites from 1988 to 1993 (Neuenschwander et al., 1994).

Impact of $G$. tebygi on populations of $R$. invadens was demonstrated by exclusion experiments and population dynamic studies (Agricola et al., 1989; Matokot et al., 1992; Boavida and Neuenschwander, 1995; Boavida et al., 1995). Later, this impact was demonstrated on a large scale in Benin by multiple regression analyses of survey data. It was shown that infestations and impact on plant growth were higher on improved than on local varieties, and damage was higher in towns than in villages (Bokonon-Ganta and Neuenschwander, 1995). However, reports of persistent "hot spots" of infestations despite the presence of G. tebygi (Bokonon-Ganta and Neuenschwander, 1995) led to the importation, rearing and release of a second parasitoid wasp, Anagyrus mangicola Noyes (Hymenoptera: Encyrtidae). In Benin, it was released in 15 batches from 1991 to 1993 (Neuenschwander et al., 1994).The successful establishment of this second wasp brought a further, local reduction of pest populations (Bokonon-Ganta et al., 1996). A recent study found that the parasitoids are also well established in Nigeria, and that the populations of the mango mealybug have been greatly reduced (Pitan et al., 2000).

The few studies that have been published so far on the socio-economic impact of biological control in Africa indicate a very high return to the investment. A first study on the biological control of the cassava mealybug by Norgaard (1988) consisted of a simple benefit-cost analysis for the "reasonable, least favorable" case. Biological control was shown to be highly cost effective, with a benefit-cost ratio of 149:1, but the lack of data did not allow for deeper analysis. Several years later, a new study on the same project, using detailed regional data over a longer period of time, resulted in a remarkably similar figure of 199:1 (Zeddies et al., 2000). Preliminary results of on-going studies on the water hyacinth and the cassava green mite also indicate high returns to investment (IITA, Plant Health Management Division, unpublished data). An recent economic study of the biological control of the spiny blackfly on an estate in Swaziland found a benefit-cost ration of 2.8, over only one season (Van Den Berg et al., 2000). This result, modest compared to the other projects, is still very favorable since most of the benefits of the above examples are only realized several years after the establishment of the predator of the imported pest. A preliminary study on the mango mealybug in Togo (Vögele et al., 1991) indicated that benefits outweighed costs, but without the proper benefit-cost analysis that the present study provides.

The present study evaluates the impact of the biological control project of the mango mealybug in Benin from a sociological and economic point of view. Lack of official statistics about mango production in Benin, complications arising from alternate bearing of mango trees, and the widely observed unnecessary tree felling following the attack by the mango mealybug complicated the economic analysis. The study documents the impact of mango mealybug and its biological control by measuring mango yields and prices, before and after the establishment of the natural enemies, and by registering the perceptions of producers concerning the evolution of mango production from the beginning of the invasion until 10 years later. Calculated benefits are then compared with the cost of the biological control programme.

\section{Methodology}

\subsection{Survey area}

This study was conducted in the Republic of Benin, in West Africa. This country is situated between latitude $6^{\circ} 30^{\prime} \mathrm{N}$ and $12^{\circ} 30^{\prime} \mathrm{N}$ and longitude $1^{\circ} 00^{\prime} \mathrm{E}$ and $3^{\circ} 40^{\prime} \mathrm{E}$, with a total land area of $112,622 \mathrm{~km}^{2}$. It extends along the Gulf of Guinea for about $125 \mathrm{~km}$ and has a length of about $750 \mathrm{~km}$. The country is presently divided into twelve provinces. When the socio-economic study started, the country was divided 
into six provinces, namely, Ouémé, Atlantique and Mono in the south; Zou, in the center; and Borgou and Atacora in the north. In 1992, about 4,600,000 inhabitants were registered, $60 \%$ of whom in the three southern provinces. The country of mostly flat topography is characterized by highly variable amounts of rainfall (Adam and Boko, 1983).

The economy is essentially subsistence agriculture, which occupies more than $70 \%$ of the population. Fruit trees such as mango, citrus, avocado, and "pomme d'Afrique", Irvingia gabonensis Baillon (Irvingiaceae), are widely sold on local markets. Reforestation programmes inaugurated to counter desertification concentrate on fast growing species, but include mango trees as multipurpose tree.

\subsection{Data collection and sampling}

To assess the socio-economic impact of biological control on mango mealybug and mango production in Benin, all six provinces were covered. Towns or localities were chosen randomly among a list of localities infested by the mango mealybug. In each of the four southern provinces, three localities were selected. In the two northern provinces, where the spread of the mango mealybug was not continuous at the time of the first surveys, only three localities were retained, representing only the affected areas. Overall, a total of 15 localities were retained. In each, 20 mango producers were drawn at random from lists obtained from the regional rural extension services (CARDER). Thus, a sample of 300 producers was considered, to represent the whole infested area.

Three consecutive surveys were conducted from 1989 to 1991 based on a semi-structured questionnaire designed for mango producers. Information obtained in the interview concerned the host plant, the pest and its social effects, the control efforts and damage of the pest on the production of fruit trees. To assess the impact of the biological control program, a final survey was conducted in 1999, based on the same trees.

\subsection{Data analysis}

Often, descriptive data were adequate for demonstrating existing trends. Respondents were judged by the coherence and veracity of responses to questions asked throughout the interview and a degree of confidence ranking from 1 (lowest) to 5 (best) attributed to each of them. For the analysis, respondents with a score between 1 and 2 were judged unreliable and were, therefore, not taken into account. Those respondents were found to be suspicious of the interviewers, or the data they produced were judged highly unlikely. To preserve the quality of the analysis, these answers were discarded. Respondents whose mango trees had just started bearing fruits (25) were also not taken into account. Thus, a total of 142 producers were retained from the sample of 300 producers, who had been interviewed. The final sample reflects the geographic and ethnic subdivision of the country and includes farmers of different social groups and professions.

In Benin, men control most of the land and own most of the trees, and fruit production usually falls under their management. As a result, the random selection of mango producers produced only 5 women out of a sample of 142. Unfortunately, this small subsample did not allow for any gender analysis.

The impact of the introduced insect pest was estimated by comparing the mean production by the same farmers at the height of the infestation with the average production of the last few years, after the successful establishment of the biological control programme. Since no other major changes had taken place during the period of study, the change in production could be attributed to the impact of the mango mealybug and its biological control. No major varieties or extension projects had been launched, and no new commercial outlets had been developed. Discussions with farmers and extension agents, combined with personal observation by the authors, revealed that no new methods of cultivation such as a change in density were being adopted, nor had there been a change in input use such as new varieties, fertilizer, or irrigation. Although there is a clear difference in quality and value between local mangoes (small and fibrous) and the fruit of grafted varieties, there was no reason to assume a change in the ratio of grafted to ungrafted mangoes. Finally, production of mango trees evolves as they age, but this effect has been minimized by taking into account only those trees in normal, full production. Under the above assumptions, the change in production could be assumed to be caused by the change in mango mealybug population. This assumption was confirmed by discussions with farmers as well as extension agents. 
The estimations of the benefits, together with cost estimates for the introduction, rearing and release of the natural enemies, are used for the benefit-cost analysis of the biological control project. The benefits and costs were discounted at the rate of $10 \%$ per annum (current interest rate), and accumulated over a period of 20 years. The present value of benefits accrued after this period was assumed negligible, since their value becomes small in comparison with the precision of the results.

\section{Results}

\subsection{Importance of mangoes in Benin}

Benin is one of the poorest countries in the world. In 1998, it had a population of 6 million people, growing at a rate of $3.3 \%$ per year, and a gross national product (GNP) per capita of US\$ 380 (World Bank, 1999). The political situation is stable, democracy seems to be established, and the economy is taking off, with a GNP of US\$2.3 billion, growing at $4.5 \%$ yearly. Benin is still a largely rural country, with $39 \%$ of its GDP coming from agriculture, although commerce is becoming increasingly important. It has two distinct agro-ecological zones: the three southern provinces have the characteristic two rainy seasons of the derived savannah, while the other provinces fall in the Guinea savannah and have only one rainy season.

The mango is a large tree that can reach $30 \mathrm{~m}$ in height (de Laroussilhe, 1980). It is very popular in West Africa for its fruit and its shade. Mangoes can be produced in plantations, with a typical density of 100 trees/ha, or scattered in villages, towns and fields. Yields vary between 50 and $200 \mathrm{~kg}$ per tree (5-20 t/ha). Production statistics for mangoes are hard to come by. D'Almeida (1995) estimates the harvested area in Benin at 1191 ha (of which $90 \%$ are found in the three northern provinces) with a production of 10,166t in 1994. The Food and Agriculture Organization (FAO) estimated the harvested area in 1998 at $2300 \mathrm{ha}$, with a yearly production at $12,000 \mathrm{t}$ per year, valued at US\$300,000 (US\$ 25/t) (FAO, 1999). These statistics seem to include only plantations, not the scattered trees found all over the country. Vögele et al. (1991), working in neighboring Togo, estimated that, in addition to the FAO statistic, each household has at least two trees of local varieties, with a production of $20 \mathrm{~kg}$ per tree. The total value of mango production in Togo, a country smaller than Benin, is, thus, estimated at US\$ 3.18 million. However, the present survey indicates that farmers in the infested area of Benin have far more trees, and the average value of mango production was estimated at US\$ 450 per farmer. Assuming 70\% of Benin's household live in rural areas and half of them are mango producers, this would result in a production value of US\$ 65 million for all households in the infested area, which is slightly more than a third of the country.

\subsection{The mango tree in Benin's farming systems}

The survey revealed the basic characteristics of mango producers. Three distinct groups were found, based on the number and spatial distribution of their fruit trees. The first group (40\% of all producers) had only few isolated trees around their houses; the second group (49\%) possessed fruit trees arranged in well-structured orchards; while the third group (11\%) had both well-structured orchards and isolated trees. The biggest orchards were found in the northern part of the country, especially in the northeast, where the mean number of trees was 1203 per orchard of over 2 ha in two thirds of all cases.

Although the names of different mango varieties were recorded, only two categories were retained, local varieties with small fibrous fruits, the so-called 'mangotiers', and grafted varieties with large fruits without fibers. Among all producers, $78 \%$ preferred grafted varieties because of the good quality of the fruits and their high commercial value. Other advantages reported by the producers were the small size of trees, and their early production. By contrast, local varieties were preferred because of the free availability of the seedlings, the high fruit production, the long lasting nature of the 'mangotiers', and the value of the fruit on the local market. Other reasons included the resistance of the 'mangotiers' to insect pests and climatic stress, and the risk attributed to the consumption of fruit of improved varieties, which are thought to be incompatible with a local alcoholic drink called "Sodabi".

Mango production in Benin generally involves very little special cultural practices. In the northern 
provinces, mango trees are found scattered around houses, towns and fields while plantations are found in the valley bottoms (bas-fonds), where they play a major role in water control. In the south, there are fewer plantations, but individual trees are found throughout. Inputs such as fertilizer and pesticides are rarely used, and none of the plantations in the survey was irrigated. The major input is the increased use of grafted varieties.

In Benin, men are responsible for the cultivation and the management of the trees, while women take part in the marketing. The production, however, belongs to the tree owners, which are usually male. Most fruit is sold on local markets and there is no processing industry.

\subsection{Objectives of mango cultivation}

The major purpose of planting mango trees is fruit production, for home consumption as well as for the market. The fruit is high in sugar and vitamin content, especially Vitamin A (de Laroussilhe, 1980). In towns, it is a valuable dessert fruit and, in the rural areas, it can replace whole meals during working days in the field. Almost all producers interviewed (99\%), said they consumed mango fruits. Of these, $87 \%$ underlined the added importance of mango for combating diseases. Among all interviewed producers, 99\% declared they had planted mango for fruit production and as a cash crop.

Mango was also considered highly valuable for its shade (30\% of the producers). Various community activities are held under the trees, such as formal and informal meetings, games, and commercial activities. Because of the size of the tree and the density of its foliage, mangoes are often planted in yards of schools and administrative buildings, or along avenues and in parks, where social and commercial activities take place (although trees in these public spaces were not included in the sample).

Different parts of the mango tree are used in the composition of various medicinal recipes to combat diseases. Additional uses like protection of the soil against erosion and rootstock production for nurseries were also mentioned. When the tree is trimmed, the leaves are used for as animal feed and the wood for fuel.

\subsection{Relative importance of different mango pests}

The main problem, mentioned by mango producers throughout the survey, was the infestation of mango trees by the mango mealybug. All producers had some knowledge of the mango mealybug. The names given varied from insect to disease or both. One of the best definitions recorded for the pest was "A white worm with black powder, producing honey-like oil". All producers declared the mango mealybug a pest and $97 \%$ answered that it decreased fruit production. In $68 \%$ of all cases, the incidence of the pest was considered higher in the dry season than in the rainy season.

Premature flower and fruit drop, probably due to fruit flies and lepidopteran species and not further addressed in the present surveys, were mentioned by $30 \%$. The infestation of trees by the spiraling white fly, Aleurodicus dispersus (Russell) (Homoptera: Aleyrodidae) was an important concern to $23 \%$ of all producers. Many farmers cited the red ant, Oecophilla smaragdina (F.) (Hymenoptera: Formicidae), as an important constraint, while others pointed out termites, caterpillars, aphids and grasshoppers. Many of these pests have damages at sub-economic levels and become serious pests only locally, as a result of changes in cultural practices or indiscriminate use of pesticides.

\subsection{Efforts to control the mango mealybug}

Of all producers, $46 \%$ tried chemical control of the mango mealybug. Even when most effective chemicals were used, treatments were stopped after a short time due to the high cost of the pesticides and the adapted sprayers. Outbreaks invariably resumed again. Trimming the trees has been used by $21 \%$ of producers who considered it a control measure for the pest. Sometimes, both mechanical (i.e. trimming) and chemical treatments were combined. Other control measures included the use of ashes, burning of tyres under the trees, the use of fertilizers, and the application of kerosene or drained-off motor oil.

All these control measures either did not control the pest at all, or only controlled it partially or for a short period. Only $9 \%$ of all producers expressed some satisfaction about the control measure they had used. 


\subsection{Awareness of biological control}

Responses of the 142 producers were assessed to evaluate their knowledge of the biological control project against the pest and the impact on fruit production after the implementation of the biological control programme. A high percentage (92\%) of all producers had some general knowledge of the theory and practice of biological control. Of these, 94\% had heard about the releases of natural enemies against the mango mealybug. Most believed that the observed increase in the production of their trees was due to biological control, but one-fifth attributed it to weather, and the remaining five had no opinion. The general awareness among the population of the potential benefits of biological control was certainly the main positive social impact of this project.

\subsection{Impact of mango mealybug and its control}

The mango mealybug secrets honeydew and, soon after infestation, the mango leaves are covered with a black sooty mould. This mould, considered by some producers as a separate disease, reduces photosynthesis and thereby fruit production. It also attracts numerous flies and other insects, virtually preventing social activities under the infested trees. Without treatment, the trees are no longer useful and need to be cut. The successful biological control of mango mealybug, therefore, has had a clear impact on fruit production, on nutrition and health, and on social activities.

The most important impact of the pest is on fruit production. The economic value of the abated loss is calculated in the next section, but a decrease in fruit production also has an immediate effect on energy intake, especially by the rural population. Indirect effects on general health can also be expected due to a decrease in Vitamin A intake, as well as from a decreased availability of traditional medicine derived from the mango tree. The black sooty mould on leaves makes all plant material unsuitable for medicinal purposes.

The great majority of respondents did not observe any direct harmful effect of the pest on humans and domestic animals. There were about 30 responses of negative effects, but none were based on first-hand observations. Claims ranged from stomach aches and diarrhea as a result of consuming food contaminated by the mealybugs, to infested leaves being toxic to domestic animals, requiring that they be kept tied up to avoid their consumption. After fruit production, the most important impact of the pest is the loss of the mango as a shade tree. The numerous social and economic activities that take place under the tree need to be transferred elsewhere, or the trees need to be replaced by other species or hangars. Given the size of mango trees and the dense shade it produces, this would entail substantial costs or delays.

Biological control of the mango mealybug has not produced any side effects on health or biodiversity. The wasps are not harmful to humans and do not have an effect on the biodiversity of the system (Neuenschwander and Markham, 2001). Since farmers hardly used any pesticides against the mango mealybug, no reduction in pesticide use can be attributed to the biological control. Biological control also has had no impact on the farm management. The rearing and release of the parasitoid was done by the project and the farmers did not need to contribute in labor or in any other way.

\subsection{Economic impact of the biological control of mango mealybugg}

To calculate the impact of biological control of mango mealybug, the situation before and after biological control was compared. The evolution of the pest, according to villagers' observations, differed slightly between the three zones (Table 1). In the three southern provinces (Mono, Atlantique and Ouémé) as well as in the central province (Zou), the pest was first noticed in 1986 by all interviewed farmers, and was considered under control by 1989 . The peak of infestation was generally placed in 1988, except for part of the Mono province. In the northern provinces (Atacora and Borgou), the pest was observed a year later than in the south, in 1987, and peaked in 1988. Its decline was first observed in 1989, and successful control was achieved in 1990.

Economic impact of $R$. invadens on fruit production and the effect of G. tebygi on this pest is reflected in the average production figures, based on estimations from the producers. Yields showed a severe depression from 1986 to 1990 , the peak of the mealybug attack (see Fig. 1 for grafted mangoes; local varieties showed a similar evolution). After a recovery from 1991 to 1992, yields stayed fairly stable from 1993 to 1996 . The 
Table 1

Villagers' observations of the arrival, peak and decline of the mango mealybug infestation in the Republic of Benin, 1986-1990 ${ }^{\mathrm{a}}$

\begin{tabular}{|c|c|c|c|c|c|c|c|c|}
\hline Province & Location & 1986 & 1987 & 1988 & 1989 & 1990 & Villages $(N)$ & Farms $(N)$ \\
\hline Mono & Aplahouè, Comè & A & $\mathrm{P}$ & B & S & & 2 & 20 \\
\hline Mono & Dogbo & A & & $\mathrm{P}, \mathrm{B}$ & $\mathrm{S}$ & & 1 & 9 \\
\hline Ouémé & All & A & & $\mathrm{P}, \mathrm{B}$ & S & & 3 & 34 \\
\hline Atlantique & All & A & & $\mathrm{P}, \mathrm{B}$ & S & & 3 & 32 \\
\hline Zou & All & A & & $\mathrm{P}, \mathrm{B}$ & $\mathrm{S}$ & & 3 & 29 \\
\hline Atacora & All & & A & $P$ & $\mathrm{~B}$ & $\mathrm{~S}$ & 2 & 12 \\
\hline Borgou & All & & A & $\mathrm{P}$ & B & $\mathrm{S}$ & 1 & 6 \\
\hline
\end{tabular}

${ }^{\text {a }}$ A: arrival; P: peak of infestation; B: beginning of decline; S: success of control.

average yield during the infestation period is from 1986 to 1990 , while the average yield after recovery covered the period from 1993 to 1996. The results (Table 2) show that yields of local varieties decreased to $26 \mathrm{~kg}$ per tree, and recovered to $84 \mathrm{~kg}$ per tree. Grafted varieties, on the other hand, went from 8 to $55 \mathrm{~kg}$ per tree, their lower yield being explained by the fact that these trees were generally younger than the local varieties. The overall yield loss due to infestation by mango mealybug was estimated at $89 \%$. Ten years after the establishment of the biological control programme, fruit production had increased significantly to $142 \%$ of the production before the introduction by the pest. This production increase was due to an increase in yield as well as an increase in the number of trees planted. Since no other changes in cultural practices had been observed, the increase in yield was only attributed to a reduction of the infestation due to G. tebygi.

\subsection{Benefit-cost analysis}

The productivity of grafted trees was lower than that of local trees. Fruits from grafted trees sold for $200 \mathrm{FCFA} / \mathrm{kg}$ during the infestation period, $100 \mathrm{FCFA} / \mathrm{kg}$ afterwards, whereas local varieties fetched $50 \mathrm{FCFA} / \mathrm{kg}$ during the infestation period and $30 \mathrm{FCFA} / \mathrm{kg}$ afterwards. Total production (number of trees $\times$ yield) at those prices gave an estimate of the value of mango production (Table 3). Translated into US dollars (US\$ $1=620$ FCFA, in 1999), it could be shown that each mango farmer gained on average

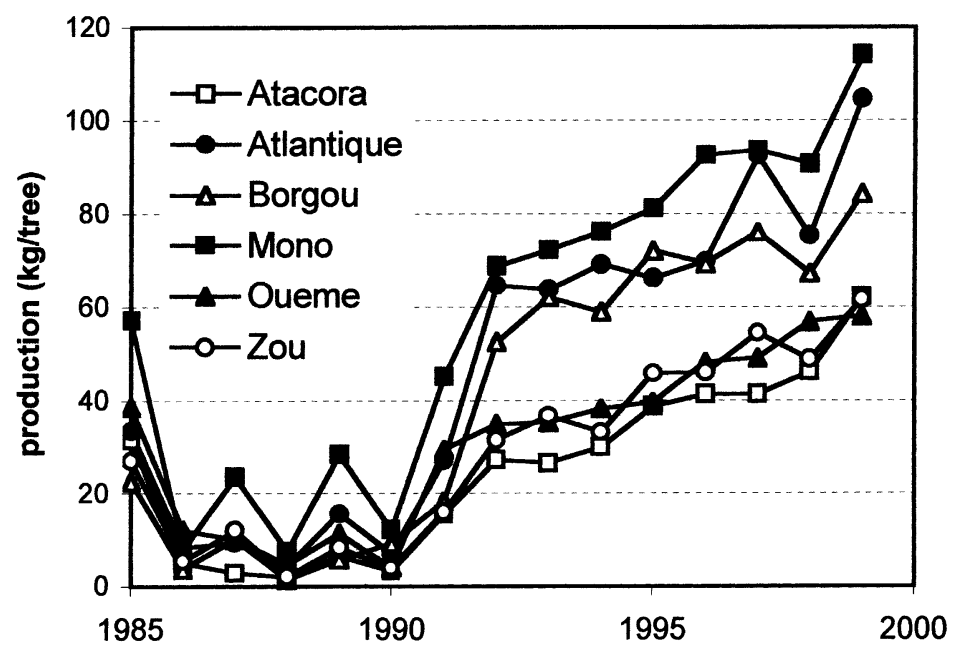

Fig. 1. Evolution of mango yields as affected by the invasion of the mango mealybug, Rastrococcus invadens and its successful biological control, on grafted varieties in six provinces of the Republic of Benin from 1985 to 1999. 
Table 2

Yields of mango trees during and after the mango mealybug infection in the Republic of Benin, 1986-1999

\begin{tabular}{|c|c|c|c|c|c|c|c|c|}
\hline \multirow[t]{3}{*}{ Province } & \multicolumn{4}{|c|}{ Local varieties } & \multicolumn{4}{|c|}{ Grafted varieties } \\
\hline & \multicolumn{2}{|c|}{ Number of trees per farmer } & \multicolumn{2}{|c|}{ Yield (kg per tree) } & \multicolumn{2}{|c|}{ Number of trees per farmer } & \multicolumn{2}{|c|}{ Yield (kg per tree) } \\
\hline & 1991 & 1999 & $1986-1990$ & 1993-1996 & 1991 & 1999 & $1986-1990$ & 1993-1996 \\
\hline Atacora & 2.4 & 2.8 & 25.55 & 41.16 & 21.3 & 31.8 & 4.03 & 34.21 \\
\hline Atlantique & 2.2 & 2.9 & 26.44 & 120.20 & 42.4 & 50.4 & 9.05 & 67.23 \\
\hline Borgou & 1.0 & 1.7 & 21.25 & 100.00 & 121.3 & 180.5 & 6.12 & 65.57 \\
\hline Mono & 4.0 & 5.9 & 17.81 & 75.19 & 15.1 & 25.2 & 15.98 & 80.55 \\
\hline Ouémé & 6.6 & 8.0 & 26.17 & 94.52 & 34.8 & 35.8 & 8.53 & 40.40 \\
\hline Zou & 4.3 & 4.1 & 37.83 & 75.04 & 40.1 & 52.0 & 6.46 & 40.47 \\
\hline Average & 4.0 & 4.9 & 26.26 & 83.80 & 36.1 & 8.37 & 8.37 & 55.07 \\
\hline
\end{tabular}

US\$ 328 per year through the biological control programme. This gain was substantially higher in the Atlantique and Borgou than in the other provinces.

These average benefits were extrapolated over the whole country. First the number of households for each province (first column in Table 4) was multiplied by the proportion of rural households (second column) and the proportion of the province affected (third column). Assuming half the households in the affected areas produce mangos, this number is divided by half, and than multiplied by the average benefit by farmer, to obtain the total yearly gain in that province. The total gain for the country is estimated at US\$ 50 million, $70 \%$ of it realized in the three southern provinces (Table 4). This figure represents the loss due to mango mealybug at the height of its infestation.
To calculate the total present value of all accrued benefits, the current situation needs to be compared with what would have happened without the biological control. For this hypothetical situation, some additional assumptions are made, illustrated in Fig. 2. The top, full line represents the evolution as experienced by farmers. To use a conservative estimate, it is was assumed that the losses started in 1988 and reached their peak in 1991. Due to the biological control, recovery was swift and by 1993 production was back at its full potential.

This evolution now needs to be compared with the hypothetical situation without biocontrol. Alternative control methods were not popular, so it is likely that farmers would have cut the infested trees and planted other species or crops. Since most fruit trees take 5-10

Table 3

Production, per mango farmer in the Republic of Benin, 1986-1999, before and after the introduction of the mango mealybug

\begin{tabular}{|c|c|c|c|c|c|c|c|c|c|}
\hline \multirow[t]{3}{*}{ Province } & \multicolumn{4}{|c|}{ Production (kg per farmer) } & \multicolumn{3}{|c|}{ Total value (FCFA per farmer) } & \multirow{3}{*}{$\begin{array}{l}\text { Gain } \\
\text { (US\$ per farmer) }\end{array}$} & \multirow[t]{3}{*}{$N$} \\
\hline & \multicolumn{2}{|c|}{ Local variety } & \multicolumn{2}{|c|}{ Grafted variety } & \multirow[t]{2}{*}{ Before } & \multirow[t]{2}{*}{ After } & \multirow[t]{2}{*}{ Gain } & & \\
\hline & Before & After & Before & After & & & & & \\
\hline Atacora & 51 & 165 & 91 & 1026 & 21743 & 107561 & 85818 & 138 & 12 \\
\hline Atlantique & 58 & 338 & 354 & 3651 & 74849 & 375198 & 300349 & 484 & 32 \\
\hline Borgou & 28 & 133 & 885 & 10721 & 178983 & 1076056 & 897072 & 1447 & 6 \\
\hline Mono & 77 & 435 & 286 & 1779 & 62550 & 190982 & 128432 & 207 & 29 \\
\hline Ouémé & 186 & 701 & 248 & 1818 & 62688 & 202773 & 140085 & 226 & 34 \\
\hline Zou & 137 & 362 & 260 & 2008 & 61496 & 211617 & 150121 & 242 & 29 \\
\hline Mean & 107 & 426 & 296 & 2571 & 66610 & 269881 & 203270 & 328 & 142 \\
\hline S.E. & 23.3 & 72.8 & 24.8 & 437.0 & 9651 & 43453 & 27123 & 59.9 & \\
\hline
\end{tabular}


Table 4

Extrapolation of the benefits of biological control of mango mealybug to the Republic of Benin 1986-1999

\begin{tabular}{|c|c|c|c|c|c|}
\hline \multirow[t]{2}{*}{ Province } & \multirow[t]{2}{*}{ Number of households ${ }^{\mathrm{a}}$} & \multicolumn{2}{|c|}{ Proportion } & \multicolumn{2}{|l|}{ Benefits } \\
\hline & & Farming & Area affected & Average gain (US\$ per farmer) & Total (US\$ 1000) \\
\hline Atacora & 92513 & 0.80 & 0.1 & 138 & 674 \\
\hline Atlantique & 205405 & 0.30 & 0.8 & 484 & 15747 \\
\hline Borgou & 108318 & 0.80 & 0.05 & 1447 & 4138 \\
\hline Mono & 131492 & 0.60 & 0.8 & 207 & 8623 \\
\hline Ouémé & 169427 & 0.60 & 0.8 & 226 & 12130 \\
\hline Zou & 150018 & 0.70 & 0.5 & 242 & 8386 \\
\hline Total & 857170 & & & 328 & 49699 \\
\hline
\end{tabular}

${ }^{a}$ MDR (1994); for the economic analysis, two-thirds of these households were judged to sell mangoes.

years to mature, alternative income would start accruing only in 1996, reaching a plateau in 2001. Given the popularity of mangoes, it can be assumed that no tree or crop can fully match them, that the value of the replacement crops would not reach more than $80 \%$ of the value of mangoes, and that it would take 5 years to reach that maximum.

For each year, the benefit of biological control is the difference between the two lines. From 1993 to 1995 this is the maximum of US\$50 million (or $76 \%$ of the affected mango production), but over the next 5 years it is reduced by one-fifth every year. Therefore, starting in 1999, the benefit to biological control of mango mealybug would be $20 \%$ of the yearly maximum gain of US\$ 50 million, or 10 million each year.

The discounted value of these benefits over 20 years added up to a present value (1999) of US\$ 531 million. This value only takes into account the effect of the increased yield. The increase in mango tree numbers that can be attributed to biological control was ignored and the number of trees was kept constant for the calculation.

IITA started the biological control programme in 1987 and it lasted over a period of 9 years. Personnel costs included an initial involvement of international scientists, to an estimated 10.1 senior scientist years

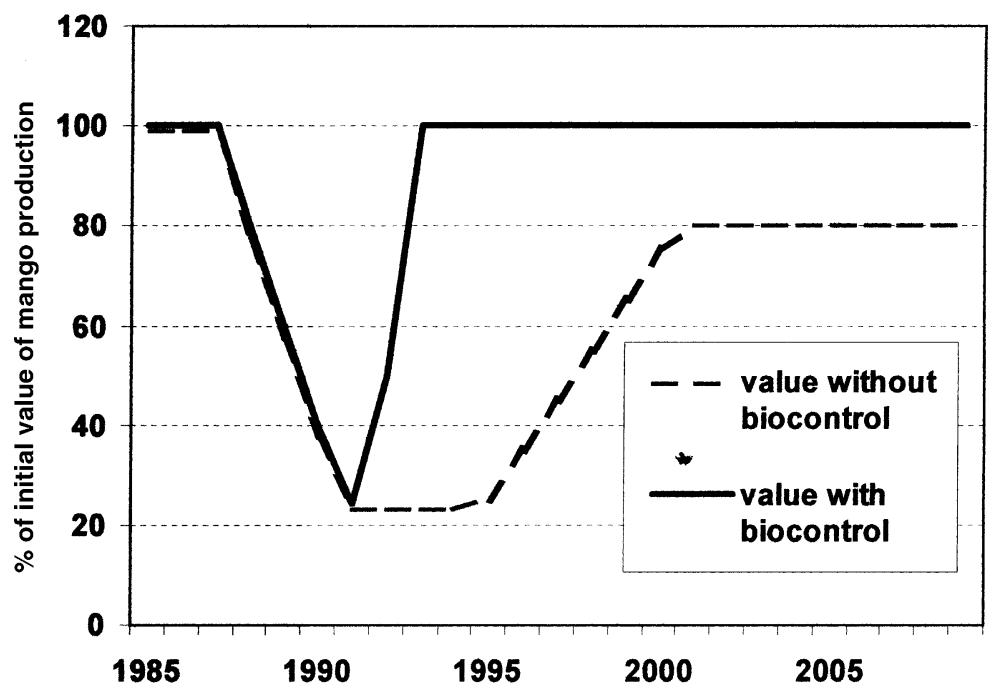

Fig. 2. Assumed evolution of the value of mango production without and with biological control (the difference between the two lines represents the yearly benefit due to the biological control, in \% of the crop value). 
Table 5

Cost of biological control of mango mealybug in the Republic of Benin (actual costs from 1987 to 1995 with present value 1999)

\begin{tabular}{|c|c|c|c|c|}
\hline Organization & Description & Staff years & Cost (US\$) & Cost with PV (1999 US\$) \\
\hline IITA & $\begin{array}{l}\text { International staff } \\
\text { Ph.D. students } \\
\text { Technical staff } \\
\text { Operational cost }\end{array}$ & $\begin{array}{l}10.1 \\
11 \\
22\end{array}$ & $\begin{array}{r}732,000 \\
200,000 \\
74,400 \\
80,000\end{array}$ & $\begin{array}{r}1,163,799 \\
330,764 \\
122,999 \\
132,306\end{array}$ \\
\hline GTZ & International staff support to NARES & & 590,000 & 773,133 \\
\hline FAO & Conference & & 30,000 & 33,333 \\
\hline IIBC & Consultants & & 600,000 & 832,211 \\
\hline SPV Bénin & Staff costs & & 180,000 & 275,365 \\
\hline Total & & & $2,486,400$ & $3,663,909$ \\
\hline
\end{tabular}

(Table 5), assisted by two Ph.D. students for a total of 11 staff years. After the successful establishment of the natural enemies, this involvement was gradually reduced, and monitoring activities were transferred to technical staff, to a total of 22 staff years. For each year, the cost of the project consisted of the staff costs of the three different categories plus operational costs. The yearly costs were discounted to the present value, and summed up to IITA's estimated involvement of US\$ 1.75 million (Table 5). Other organizations, funded separately, offered support: GTZ, FAO, CABI, and the Benin plant protection services. The total cost of biological control of mango mealybug in Benin, taking into account the initial activities in Togo, amounted to US\$3.66 million Compared to the benefit of US\$ 531 million, the benefit-cost ratio was calculated at 145:1.

\section{Discussion}

The importance of mango cultivation in Benin was shown in these surveys through the various uses made of the tree and its fruits. In India, mango is also important in various ceremonial functions (Singh, 1968); but this aspect was not recorded in the present survey.

In the present analysis, the previously quantified impact of the pest and the resultant sooty mould on plant growth (Bokonon-Ganta and Neuenschwander, 1995) was extended to include fruit production and revenue for the farmer.
The overall failure of various individual control measures undertaken by producers resulted in a general panic. Because a perennial plant providing shade and fruits was threatened, the whole community, including decision-makers in towns, became concerned. The capability of the introduced natural enemy, $G$. tebygi to reduce populations of $R$. invadens was well recognized by the producers. Most attributed the observed improvement to the success of biological control, and only $15 \%$ of the producers attributed the improvement in fruit production primarily to weather factors, thus, confirming previous survey data (Bokonon-Ganta and Neuenschwander, 1995). Similar observations on the awareness amongst the local population of the value and practice of biological control of $R$. invadens had been made by Vögele et al. (1991) in Togo. By contrast, in a study on the impact of biological control against the cassava mealybug, Phenacoccus manihoti Matile-Ferrero (Homoptera: Pseudococcidae), the majority of farmers recognized improvement, but attributed it to weather (Neuenschwander et al., 1989).

Estimates by producers confirmed the negative impact of the pest on plant production and the positive impact of the introduced natural enemy. Production did not immediately return to pre-infestation levels, probably due to the effect of the residual sooty mould on trees following the releases of G. tebygi. A similar impact of the introduced natural enemy had been assessed in Togo based on estimation of the production of a limited number of trees grown from the main seedling nurseries (Vögele et al., 1991). An increase 
beyond the original mango production is attributed to the fact that during the last 10 years many new mango orchards had been established and were coming into production. To what extent the second parasitoid, A. mangicola, which was established later (Neuenschwander et al., 1994; Neuenschwander, 1996), contributed to the decline of the mealybug populations and increased mango production remains unknown.

The present study clearly demonstrated the recognition by the producers of the success of this biological control project. This can be summarized in the benefit-cost ratio of 145:1, which was based on initial costs in Togo and costs and benefits in Benin. The two parasitoids were later distributed over all of West Africa and some countries in Central Africa at little additional costs (Neuenschwander et al., 1994, and unpublished results by the same authors). Therefore, the benefit-cost ratio for the biological control of mango mealybug for the whole region is likely to be substantially higher.

\section{Acknowledgements}

This work was financed by the Swiss Development Cooperation (SDC), Switzerland, GTZ, Germany, and the Government of Austria. We thank all the donors of IITA's Biological Control Programme for their financial and material support. We are grateful to all enumerators of the extension services (CARDER) for their contribution to the execution of the surveys and the staff of the "Direction de l'Agriculture", especially the Plant Protection Service, for their encouragement, support, and assistance during the execution of this programme. Our sincere thanks are due to S. Attignon, P. Dossa, R. Badou and Douro Kpindou of IITA for their assistance during the course of processing of these data, and to Dennis Friesen for his help with editing. The present paper carries IITA manuscript number IITA/00/JA/74.

\section{References}

Adam, K.S., Boko, M., 1983. Le Bénin. Sodimas, Cotonou, Bénin. Agounkè, D., Agricola, U., Bokonon-Ganta, H.A., 1988. Rastrococcus invadens Williams (Hemiptera: Pseudococcidae), a serious pest of fruit trees and other plants in West Africa. Bull. Entomol. Res. 78, 695-702.
Agricola, U., Agounkè, D., Fischer, H.U., Moore, D., 1989. The control of Rastrococcus invadens Williams (Hemiptera: Pseudococcidae) in Togo by the introduction of Gyranusoidea tebygi Noyes (Hymenoptera: Encyrtidae). Bull. Entomol. Res. 79, 671-678.

Boavida, C., Neuenschwander, P., 1995. Population dynamics and life tables of the mango mealybug, Rastrococcus invadens Williams and its introduced natural enemy, Gyranusoidea tebygi Noyes in Benin. Biocontrol Sci. Technol. 5, 489-508.

Boavida, C., Neuenschwander, P., Herren, H.R., 1995. Experimental assessment of the impact of the introduced parasitoid Gyranusoidea tebygi Noyes on the mango mealybug Rastrococcus invadens Williams by a physical exclusion method. Biol. Control 5, 99-103.

Bokonon-Ganta, A.H., Neuenschwander, P., 1995. The impact of the biological control agent Gyranusoidea tebygi Noyes (Hymenoptera: Encyrtidae), on the mango mealybug, Rastrococcus invadens Williams (Homoptera: Pseudococcidae) in Benin. Biocontrol Sci. Technol. 5, 95-107.

Bokonon-Ganta, A.H., van Alphen, J.J.M., Neuenschwander, P., 1996. Competition between Gyranusoidea tebygi and Anagyrus mangicola, parasitoids of the mango mealybug, Rastrococcus invadens: interspecific host discrimination and larval competition. Entomol. Exp. Appl. 79, 179-185.

de Laroussilhe, F., 1980. In: Manguier L. (Ed.), Maisonneuve et Larose. Paris, France, 312 pp.

D'Almeida, J.P., 1995. Situation actuelle de la production fruitière en République du Bénin. Rapport de consultation pour la FAO, TCP/BEN/4553.

Food and Agriculture Organization. 1999. Production Year Book 1998. FAO, Rome.

Litz, R.E., 1997. The Mango: Botany, Production and Uses. CAB International, University Press, Cambridge, $587 \mathrm{pp}$.

Matokot, L., Reyd, G., Malonga, P., Le Ru,, B., 1992. Dynamique des populations de Rastrococcus invadens (Hom.: Pseudococcidae) au Congo influence de l'introduction accidentelle du parasitoide asiatique Gyranusoidea tebygi (Hym.: Encyrtidae). Entomophaga 37, 123-140.

Ministère du Développement Rural, 1994. Rapport de l'Enquête Statistique 1992-1993, in: Tableaux statistiques, Vol. 2. MDR, Service de la StatistiqueAgricole, Cotonou.

Narasimham, A.U., Chacko, M.J., 1988. Rastrococcus spp. (Hemiptera: Pseudococcidae) and their natural enemies in India as potential biocontrol agents for Rastrococcus invadens Williams. Bull. Entomol. Res. 78, 703-708.

Neuenschwander, P., 1996. Evaluating the efficacy of biological control of three exotic homopteran pests in tropical Africa. Entomophaga 41, 405-424.

Neuenschwander, P., Markham, R., 2001. Biological control in Africa and its possible effects on biodiversity. In: Wajnberg, E., Scott, J.K., Quimby, P.C. (Eds.), Evaluating Indirect Ecological Effects of Biological Control. CAB International, University Press, Cambridge, pp. 127-146.

Neuenschwander, P., Hammond, W.N.O., Gutierrez, A.P., Cudjoe, A.R., Adjakloe, R., Baumgärtner, J.U., Regev, U., 1989. Impact assessment of the biological control of the cassava mealybug, Phenacoccus manihoti Matile-Ferrero (Hemiptera: 
Pseudococcidae), and its introduced parasitoid, Epidinocarsis lopezi (De Santis) (Hymenoptera: Encyrtidae). Bull. Entomol. Res. 79, 579-594.

Neuenschwander, P., Boavida, C., Bokonon-Ganta, A., Gado, A., Herren, H.R., 1994. Establishment and spread of Gyranusoidea tebygi Noyes and Anagyrus mangicola Noyes (Hymenoptera: Encyrtidae), two biological control agents released against the mango mealybug Rastrococcus invadens Williams (Homoptera: Pseudoccocidae) in Africa. Biocontrol Sci. Technol. 4, 61-69.

Norgaard, R.B., 1988. The biological control of the cassava mealybug in Africa. Am. J. Agric. Econ. 70, 366-371.

Pitan, O.O., Akinlosotu, T.A., Odebiyi, J.A., 2000. Impact of Gyranusoidea tebygi Noyes (Hymenoptera: Encyrtidae) on the Mango mealybug, Rastrococcus invadens Williams (Homoptera: Pseudococcidae) in Nigeria. Biocontrol Sci. Technol. 10, 245254.

Singh, L.B., 1968. The Mango: Botany, Cultivation and Utilization. World Crop Books, Leonard Hill, London, 438 pp.

Van Den Berg, M.A., Höppner, G., Greenland, J., 2000. An economic study of the biological control of the spiny blackfly,
Aleurocanthus spiniferus (Hemiptera: Aleyrodidae), in a citrus orchard in Swaziland. Biocontrol Sci. Technol. 10, 27-32.

Vögele, J.M., Agounkè, D., Moore, D., 1991. Biological control of the fruit tree mealybug Rastrococcus invadens Williams in Togo: a preliminary sociological and economic evaluation. Trop. Pest Manage. 37, 379-382.

Williams, D.J., 1986. Rastrococcus invadens sp. n. (Hemiptera: Pseudococcidae) introduced from the oriental region to West Africa and causing damage to mango, citrus and other trees. Bull. Entomol. Res. 76, 695-699.

Willink, E., Moore, D., 1988. Aspects of the biology of Rastrococcus invadens Williams (Hemiptera: Pseudoccocidae), a pest of fruit crops in West Africa, and one of its primary parasitoids, Gyranusoidea tebygi Noyes (Hymenoptera: Encyrtidae). Bull. Entomol. Res. 78, 709-715.

World Bank. 1999. World Development Report 1999. The World Bank, Washington, DC.

Zeddies, J., Schaab, R.P., Neuenschwander, P., Herren, H.R., 2000. Economics of biological control of cassava mealybug in Africa. Agric. Econ. 24, 209-219. 